\title{
Air pollution and lung function among susceptible adult subjects: a
} panel study

\author{
Susanna Lagorio*1, Francesco Forastiere ${ }^{2}$, Riccardo Pistelli ${ }^{3}$, Ivano Iavarone ${ }^{4}$, \\ Paola Michelozzi ${ }^{2}$, Valeria Fano ${ }^{2}$, Achille Marconi ${ }^{4}$, Giovanni Ziemacki ${ }^{4}$ and \\ Bart D Ostro ${ }^{5}$
}

\begin{abstract}
Address: ${ }^{1}$ National Centre for Epidemiology, Surveillance and Health Promotion, Istituto Superiore di Sanità, Viale Regina Elena 29900161 Rome, Italy, ${ }^{2}$ Department of Epidemiology, Rome E Health Authority, Via di Santa Costanza 5300198 Rome, Italy, ${ }^{3}$ Pneumology Department, Università Cattolica del Sacro Cuore, Via Moscati 31 - 00168 Rome, Italy, ${ }^{4}$ Department of Environment and Primary Prevention, Istituto Superiore di Sanità, Viale Regina Elena 29900161 Rome, Italy and 5California Office of Environmental Health Hazard Assessment (OEHHA), 1515 Clay St., Oakland, CA 94612, USA

Email: Susanna Lagorio* - susanna.lagorio@iss.it; Francesco Forastiere - forastiere@asplazio.it; Riccardo Pistelli - columbus.fpr@linet.it; Ivano Iavarone - ivano.iavarone@iss.it; Paola Michelozzi - michelozzi@asplazio.it; Valeria Fano - fano@asplazio.it;

Achille Marconi - marconi@iss.it; Giovanni Ziemacki - ziemacki@iss.it; Bart D Ostro - BOSTRO@oehha.ca.gov

* Corresponding author
\end{abstract}

(c) 2006 Lagorio et al; licensee BioMed Central Ltd.

This is an Open Access article distributed under the terms of the Creative Commons Attribution License (http://creativecommons.org/licenses/by/2.0), which permits unrestricted use, distribution, and reproduction in any medium, provided the original work is properly cited.

\begin{abstract}
Background: Adverse health effects at relatively low levels of ambient air pollution have consistently been reported in the last years. We conducted a time-series panel study of subjects with chronic obstructive pulmonary disease (COPD), asthma, and ischemic heart disease (IHD) to evaluate whether daily levels of air pollutants have a measurable impact on the lung function of adult subjects with pre-existing lung or heart diseases.
\end{abstract}

Methods: Twenty-nine patients with COPD, asthma, or IHD underwent repeated lung function tests by supervised spirometry in two one-month surveys. Daily samples of coarse $\left(\mathrm{PM}_{10-2.5}\right)$ and fine $\left(\mathrm{PM}_{2.5}\right)$ particulate matter were collected by means of dichotomous samplers, and the dust was gravimetrically analyzed. The particulate content of selected metals (cadmium, chrome, iron, nickel, lead, platinum, vanadium, and zinc) was determined by atomic absorption spectrometry. Ambient concentrations of nitrogen dioxide $\left(\mathrm{NO}_{2}\right)$, carbon monoxide $(\mathrm{CO})$, ozone $\left(\mathrm{O}_{3}\right)$, and sulphur dioxide $\left(\mathrm{SO}_{2}\right)$ were obtained from the regional air-quality monitoring network. The relationships between concentrations of air pollutants and lung function parameters were analyzed by generalized estimating equations (GEE) for panel data.

Results: Decrements in lung function indices ( $F V C$ and/or $\mathrm{FEV}_{1}$ ) associated with increasing concentrations of $\mathrm{PM}_{2.5}, \mathrm{NO}_{2}$ and some metals (especially zinc and iron) were observed in COPD cases. Among the asthmatics, $\mathrm{NO}_{2}$ was associated with a decrease in $\mathrm{FEV}_{1}$. No association between average ambient concentrations of any air pollutant and lung function was observed among IHD cases.

Conclusion: This study suggests that the short-term negative impact of exposure to air pollutants on respiratory volume and flow is limited to individuals with already impaired respiratory function. The fine fraction of ambient PM seems responsible for the observed effects among COPD cases, with zinc and iron having a potential role via oxidative stress. The respiratory function of the relatively young and mild asthmatics included in this study seems to worsen when ambient levels of $\mathrm{NO}_{2}$ increase. 


\section{Background}

Throughout the 1990s, many epidemiological studies consistently reported adverse health effects at unexpectedly low levels of ambient air pollution [1]. Identification of susceptible sub-populations and mechanisms of effect involved are two clear research priorities [2,3]. Several chronic clinical conditions are good candidates to define the "frail" population susceptible to the acute effects of PM pollution: chronic obstructive pulmonary disease (COPD) including asthma, ischemic heart diseases (IHD), congestive heart failure, heart rhythm disorders, and diabetes [4].

The mechanisms of lung injury caused by particles among people with COPD have been reviewed [5]. The ability of particulate matter to induce oxidative stress in the airways has been proposed as an important biological mechanism [6]. The oxidative stress mediated by particles may arise from direct generation of reactive oxygen species from the surface of particles or from soluble compounds such as transition metals or organic compounds (poly-aromatic hydrocarbons) [7]. Oxidative stress might up-regulate redox sensitive transcription factors (via nuclear factor kappa B, NF-kB) in airway epithelial cells, thus increasing the synthesis of proinflammatory cytokines and resulting in cell and tissue injury [8].

In healthy and asthmatic volunteers, airborne particles increase bronchial responsiveness, airway resistance, and bronchial tissue mast cell, neutrophil, and lymphocyte counts [9]. A specific role for ultrafine particles and metallic content of PM (especially iron) has been advocated $[10,11]$.

The relationship between daily levels of air pollutants and respiratory function in patients with chronic respiratory diseases has been analyzed in various panel studies, with inconsistent results $[12,13]$. Most studies concern asthmatic children, while far fewer observations relate to changes in peak expiratory flow rate [14-22] or in spirometric flow and volume [23-26] among adult or elderly asthmatics or COPD patients.

We conducted a time-series panel study of subjects with COPD, asthma, and IHD with the aim of answering the following question: have daily fluctuations of selected air pollutants a measurable impact on the lung function of subjects with pre-existing lung or heart disease?

\section{Methods}

\section{Participant recruitment}

Study subjects were selected among outpatients of the Pneumology and Cardiology Departments of the Catholic University Hospital in Rome (UCSC) included in routine clinical follow-up programs. Eligible for the study were residents of Rome, living in census tracts less than $2 \mathrm{~km}$ away from one of the six air monitoring stations considered in this study.

A number of clinical criteria was specified for each nosological category. Eligibility for the COPD panel included age from 50 to 80 years, a ratio of forced expiratory volume in one second to forced vital capacity $\left(\mathrm{FEV}_{1} / \mathrm{FVC}\right)$ less than $60 \%$, partial oxygen pressure $\left(\mathrm{SpO}_{2}\right)$ at arterial blood oximetry $=60-70 \mathrm{mmHg}$, normal values of carboxyhemoglobin $(\mathrm{COHb})$, normal acid-base balance, no concomitant IHD, no need of oxygen therapy or breathing apparatus, no pacemaker, no cardiac arrhythmias, diabetes, Parkinson disease or chronic alcohol abuse, and no use of either psycho-chemical drugs or long acting bronchodilators; occasional use of short-acting bronchodilators was allowed.

Admittance to the asthmatic panel was allowed to subjects aged 18 to 64 years, positive at the bronchial reactivity test by hypertonic saline solution, with disease in the mild intermittent stage [27]. Occasional use of $\beta$-adrenergic stimulants was allowed, but assumption of steroids or other asthma-preventive drugs (either before, or during the study periods) was not.

Participation in the IHD panel was restricted to subjects aged 40 to 64 years, with stable angina or previous myocardial infarction (at least 1 year prior to recruitment), no concomitant COPD, no use of calcium channel blockers, no pacemaker, no atrial fibrillation (other arrhythmias admitted), diabetes, Parkinson disease or chronic alcohol abuse, and no use of psycho-chemical drugs.

In relation to smoking habits, participation in the asthmatic panel was restricted to never smokers. Never smokers, however, were almost absent from the clinical series of COPD and IHD outpatients; former smokers were then admitted to the COPD and IHD panels if they had given up smoking at least 1 year before enrollment (sustained quitters).

The study protocol was approved by the Ethical Committee of the UCSC. Twenty-nine patients with COPD (7 men and 4 women), asthma ( 5 men and 6 women) or IHD (6 men and 1 woman) gave their written informed consent to undergo repeated clinical examinations for two onemonth periods, in the spring and winter of 1999.

\section{Study time period}

The time period of interest consisted of 67 days in total, from 24 May to 24 June and from 18 November to 22 December 1999. These periods were chosen based on historical time series analyses of air pollution levels in Rome, due to their high variability in air pollutant concentrations. 
Table I: Characteristics of study subjects and group averages of lung function parameters over the survey periods

\begin{tabular}{|c|c|c|c|c|c|c|c|c|c|c|}
\hline \multirow[b]{3}{*}{ Variable (unit) } & \multirow[b]{3}{*}{ Gender } & \multicolumn{9}{|c|}{ Panel } \\
\hline & & \multicolumn{3}{|c|}{ COPD } & \multicolumn{3}{|c|}{ Asthma } & \multicolumn{3}{|c|}{ IHD } \\
\hline & & Obs & Mean & SD & Obs & Mean & SD & Obs & Mean & SD \\
\hline \multirow[t]{3}{*}{ Age (years) } & Male & 7 & 67 & 11 & 5 & 33 & 15 & 6 & 63 & 11 \\
\hline & Female & 4 & 65 & 7 & 6 & 48 & 10 & I & 64 & - \\
\hline & Total & II & 67 & 9.1 & II & 41 & 14 & 7 & 64 & 10 \\
\hline \multirow[t]{3}{*}{ BMI (kg/m²) } & Male & 7 & 27 & 6 & 5 & 25 & 4 & 6 & 26 & 3 \\
\hline & Female & 4 & 25 & 3 & 6 & 23 & 3 & 1 & 29 & - \\
\hline & Total & II & 26 & 5 & II & 24 & 3 & 7 & 26 & 3 \\
\hline \multirow[t]{3}{*}{ FVC (\% predicted) } & Male & 108 & 63 & 10 & 38 & 113 & 11 & 139 & 81 & 10 \\
\hline & Female & 63 & 61 & 9 & 70 & 116 & 12 & 31 & 80 & 4 \\
\hline & Total & $|7|$ & 63 & 10 & 108 & 115 & 12 & 170 & 81 & 9 \\
\hline \multirow[t]{3}{*}{ FEV (\% predicted) } & Male & 108 & 45 & 10 & 38 & 94 & 13 & 139 & 84 & 10 \\
\hline & Female & 63 & 47 & 10 & 70 & 96 & 18 & 31 & 84 & 5 \\
\hline & Total & $|7|$ & 45 & 10 & 108 & 95 & 16 & 170 & 84 & 10 \\
\hline \multirow{3}{*}{ NO in exhaled breath (ppb) } & Male & & & & 37 & 66 & 40 & & & \\
\hline & Female & & & & 70 & 42 & 27 & & & \\
\hline & Total & & & & 107 & 50 & 34 & & & \\
\hline
\end{tabular}

\section{Health monitoring}

Study subjects were scheduled to be examined three days apart, at home (COPD and IHD panels) or at the Pneumology Clinic of the UCSC (asthmatic panel). Forced vital capacity (FVC) and forced expiratory volume in 1 second $\left(\mathrm{FEV}_{1}\right)$ were measured by spirometry. Spirometries were supervised, and done with the subject in a sitting position and wearing a nose-clip, following the suggestions of the American Thoracic Society [28]. Spirometries were always done in the afternoon (between $4 \mathrm{pm}$ and 8 $\mathrm{pm})$, at least 6 hours after a possible inhalation of shortacting bronchodilators. A heated Fleish tube $\mathrm{n} .3$ portable spirometer (Biomedin, Italy) was used in the COPD and IHD panels, and a light bell Stead-Wells spirometer (Biomedin, Italy) in the asthmatic group. Between instruments reproducibility, for both FVC and $\mathrm{FEV}_{1}$, was within $30 \mathrm{ml}$ and the calibration procedures were regularly performed [28]. Pulmonary function indices used in the analyses are expressed as the percentage of the predicted values based on the subject- specific sex, age, height and weight [29].

Only amongst asthmatics we determined concentrations of nitric oxide (NO) in exhaled breath, an indicator of bronchial inflammation [30], using the analyzer model 280 (Sievers Instruments, USA). Subjects were breathing $\mathrm{NO}_{\mathrm{x}}$ free air prior to this test. Asthmatics were also asked to fill in a brief daily questionnaire collecting information about the occurrence of asthma attacks and $\beta-2$ agonist inhalations.

\section{Study subjects' characteristics}

Table 1 describes the characteristics of subjects at entry and the group-distribution of the outcome variables. As expected on the basis of the eligibility criteria, asthmatics were younger than COPD and IHD patients, and the group average values of $\mathrm{FVC}$ and $\mathrm{FEV}_{1}$ were sensibly lower among COPD cases compared to both IHD and asthmatic subjects. Overall, the 29 study subjects underwent a total of 449 spirometries. Due to dropouts, a variable number of observations per case was available. The average number of repeated observations was 15 in the COPD panel (ranging from 1 to 32 per subject), 24 in the IHD panel (from 12 to 32 per case), and 9 among the asthmatics (from 6 to 18 per person). All IHD patients were regularly treated with aspirin, statins and nitrates. No COPD or IHD patient made use of bronchodilators (short- or long-acting) during the survey periods, while 7 out of 11 asthmatics reported $\beta-2$ stimulant inhalations on one or more of the clinical monitoring days. As to previous smoking habits, all COPD patients were sustained quitters, all asthmatics were never smokers, while in the IHD panel the five male patients were sustained quitters and the single female participant was a never smoker.

\section{Environmental data}

Mean daily temperature ( $\mathrm{T}$, Celsius), barometric pressure (BarP, mmHg) and relative humidity (RelHum, \%) were available from the Rome weather station (Collegio Romano - Ufficio Centrale di Ecologia Agricola). The Department of Environment of the Latium Region provided us with hourly concentrations of nitrogen dioxide $\left(\mathrm{NO}_{2}\right)$, carbon monoxide $(\mathrm{CO})$, ozone $\left(\mathrm{O}_{3}\right)$, and sulphur 
dioxide $\left(\mathrm{SO}_{2}\right)$ recorded at the fixed sites for air-quality monitoring in Rome. These sites are equipped with continuous inlet samplers. $\mathrm{NO}_{2}$ is determined by chemiluminescence, $\mathrm{CO}$ by IR absorption, $\mathrm{O}_{3}$ by UV absorption, and $\mathrm{SO}_{2}$ by UV fluorescence.

We computed daily city means ( $24 \mathrm{~h}$ values, from $3 \mathrm{pm}$ to $3 \mathrm{pm}$ of the following day) based on data from varying type and number of sites, depending on the pollutant. For $\mathrm{NO}_{2}$ and $\mathrm{CO}$, we calculated $24 \mathrm{~h}$ values from five fixed sites, three of which are located in densely populated areas in the center of Rome (Magna Grecia, Fermi, Libia) and two representing background areas (Preneste and Villa Ada). For $\mathrm{O}_{3}$, concentrations recorded at two background fixed sites (Preneste and Villa Ada) were used. For $\mathrm{SO}_{2}$, we used $24 \mathrm{~h}$ concentrations recorded at one urban site (Fermi) and one background site (Villa Ada). The $\mathrm{NO}_{2}$ and $\mathrm{SO}_{2}$ series were complete, while average daily concentrations for one single day were missing for $\mathrm{CO}$ and $\mathrm{O}_{3}$.

As to particulate matter, we could not use data from the Rome air-quality monitoring network, because $\mathrm{PM}_{2.5}$ was not routinely measured. Therefore, for the specific purposes of this survey, $24 \mathrm{~h}$ concentrations of $\mathrm{PM}_{10-2.5}$ and $\mathrm{PM}_{2.5}$ were measured at two selected fixed monitoring sites: Villa Ada and Istituto Superiore di Sanità (ISS). These sites, located about $3.5 \mathrm{~km}$ apart, were chosen because, based on historical $\mathrm{PM}_{10}$ monitoring data, are considered representative of low and high traffic areas in Rome, respectively. Air samples were collected by means of dichotomous samplers (Graseby Andersen, model SA 241) operating at $16.7 \mathrm{~L} / \mathrm{min}$, with an omni-directional aerosol inlet. This sampler has been designated as reference for $\mathrm{PM}_{10}$ by US EPA [31]. Sampling was carried out from $3 \mathrm{pm}$ to $3 \mathrm{pm}$ of the following day (in order to match the spirometry time schedule). Sixty-two 24 hour samples were collected, with 5 missing observations at the beginning of the winter survey. The dust on the couple of sequential polytetrafluoroethylene (PTFE) filters (polymethylpentane ringed, $2.0 \mu \mathrm{m}$ pore size, $37 \mathrm{~mm}$ diameter; Gelman, USA) was gravimetrically analyzed to obtain average daily concentrations of $\mathrm{PM}_{2.5}$ and $\mathrm{PM}_{10-2.5}$. $\mathrm{PM}_{10}$ concentrations were calculated by adding the concentrations of the sampled fine and coarse fractions. The averages of PM concentrations measured at the two locations were used in the statistical analyses, as our best estimate of $24 \mathrm{~h}$ mean ambient concentrations for the Rome neighborhoods the panel participants lived in.

In the $\mathrm{PM}_{10-2.5}$ and $\mathrm{PM}_{2.5}$ samples, the content of selected metals (cadmium - $\mathrm{Cd}$, chromium - $\mathrm{Cr}$, iron - $\mathrm{Fe}$, nickel - Ni, lead - Pb, platinum - Pt, vanadium-V, and zinc $\mathrm{Zn}$ ) was determined by atomic absorption spectrometry (AAS). The concentrations used in the analysis were calcu- lated as the ratio of the metal amount in each PM sample to the air volume collected during the sampling.

As a side validation study, we measured indoor $\mathrm{PM}_{2.5}$ concentrations in a total of five homes of three study subjects per survey. COPD cases were preferentially selected for the side study due to their reduced mobility in comparison with asthmatics and IHD patients. Participation in the side validation study was burdensome to the study subjects: a technician had to come every day to change the sampler filter, and the sampler itself was noisy. Thus, we only succeeded in getting consent to participate from one IHD patient for both surveys, and from four COPD cases, for only one survey each. Participants in the side study were representative of the full study group in terms of housing typology (all lived in apartment buildings), floor [basement, first floor (two homes), second floor, fifth floor], and distance from the ISS or Villa Ada $\mathrm{PM}_{2.5}$ monitoring sites (varying from 0.3 to $5 \mathrm{~km}$ ). Indoor $24 \mathrm{~h}$ air samples were collected on 59 days (from 28 May to 24 June and from 22 November to 22 December 1999) by Micro-Environmental Monitors (SKC, model 400) with a single-stage impactor, operating at a sampling flow rate of $10 \mathrm{~L} / \mathrm{min}$ and equipped with a $\mathrm{PM}_{2.5}$ sampling inlet and PTFE filters (polymethylpentane ringed, $2.0 \mu \mathrm{m}$ pore size, $37 \mathrm{~mm}$ diameter; Gelman, USA). Indoor $\mathrm{PM}_{2.5}$ mass concentrations were gravimetrically determined. The $24 \mathrm{~h}$ average concentrations of $\mathrm{PM}_{2.5}$ from three homes per survey were used in the reproducibility analysis.

In a previous inter-method reliability study of $\mathrm{PM}_{10}$ measurements in outdoor and indoor air samples in Rome, based on two series of 12 parallel $24 \mathrm{~h}$ samples, a very good correlation between MEM and dichotomous samplers was observed (regression 1: $\mathrm{y}=1.192 \mathrm{x}-3.275-\mathrm{R}^{2}=$ 0.9506; regression 2: $\mathrm{y}=0.998 \mathrm{x}-1.332-\mathrm{R}^{2}=0.9866$ ) [32]. According to the European Standard EN 12341 criteria [33], the observed values of the determination coefficients are such that the MEM can be considered equivalent to the dichotomous sampler.

\section{Statistical analyses}

Correlations among outdoor pollutant levels, as well as those between indoor and outdoor $\mathrm{PM}_{2.5}$ concentrations, were evaluated by non-parametric tests (Spearman correlation coefficient) applied to variables in the original scale.

Outcome variables in each panel had observations missing, and there was unequal spacing (the interval between observations was not constant). There were a few missing observations in the exposure variables also $(1$ missing daily mean for both $\mathrm{O}_{3}$ and $\mathrm{CO}$ concentrations, and 5 missing daily means for $\mathrm{PM}_{2.5}$ and $\mathrm{PM}_{10-2.5}$ ). Missing 
Table 2: Concentrations of PM, metals from $\mathrm{PM}_{2.5}$, gaseous pollutants, and climatic conditions (1999 spring and winter)

\begin{tabular}{|c|c|c|c|c|c|c|c|c|c|c|c|c|c|c|c|c|c|}
\hline \multirow[t]{2}{*}{ Variable } & \multirow[t]{2}{*}{ Unit } & \multicolumn{5}{|c|}{ Spring } & \multicolumn{5}{|c|}{ Winter } & \multicolumn{6}{|c|}{ Overall } \\
\hline & & Obs & Mean & SD & GMean & IQR & Obs & Mean & SD & GMean & IQR & Mean & SD & GMean & Min & Max & IQR \\
\hline $\mathrm{PM}_{2.5}$ * & $\mu g / m^{3}$ & 32 & 18.2 & 5.0 & 17.4 & 8.1 & 30 & 36.7 & 24.1 & 27.8 & 40.9 & 27.2 & 19.4 & 21.8 & 4.5 & 100 & 22.7 \\
\hline $\mathrm{PM}_{10-2.5} *$ & $\mu \mathrm{g} / \mathrm{m}^{3}$ & 32 & 18.7 & 7.4 & 17.4 & 9.0 & 30 & 12.3 & 5.4 & 11.0 & 8.3 & 15.6 & 7.2 & 14.0 & 3.4 & 39.6 & 7.1 \\
\hline $\mathrm{PM}_{10}$ * & $\mu g / \mathrm{m}^{3}$ & 32 & 36.9 & 10.8 & 35.4 & 13.1 & 30 & 49.0 & 28.1 & 40.2 & 45.3 & 42.8 & 21.8 & 37.6 & 7.9 & 123 & 26.9 \\
\hline Cd & $\mathrm{ng} / \mathrm{m}^{3}$ & 30 & 0.29 & 0.09 & 0.27 & 0.14 & 30 & 0.63 & 0.50 & 0.47 & 0.47 & 0.46 & 0.40 & 0.36 & 0.09 & 2.0 & 0.31 \\
\hline $\mathrm{Cr}$ & $\mathrm{ng} / \mathrm{m}^{3}$ & 30 & 0.90 & 0.47 & 0.80 & 0.61 & 30 & 2.8 & 2.0 & 2.2 & 2.7 & 1.9 & 1.7 & 1.3 & 0.2 & 9.8 & 1.6 \\
\hline $\mathrm{Fe}$ & $\mathrm{ng} / \mathrm{m}^{3}$ & 30 & 339 & 180 & 303 & 212 & 30 & 227 & 132 & 190 & 208 & 283 & 167 & 240 & 54.1 & 893 & 202 \\
\hline $\mathbf{N i}$ & $\mathrm{ng} / \mathrm{m}^{3}$ & 30 & 5.1 & 4.7 & 3.6 & 4.2 & 30 & 4.6 & 8.0 & 2.7 & 2.5 & 4.8 & 6.5 & 3.1 & 1.0 & 42.3 & 2.8 \\
\hline $\mathbf{P b}$ & $\mathrm{ng} / \mathrm{m}^{3}$ & 30 & 24.4 & 9.6 & 22.2 & 15.6 & 30 & 36.8 & 23.8 & 27.7 & 33.5 & 30.6 & 19.0 & 24.8 & 2.2 & 99.8 & 19.9 \\
\hline $\mathbf{P t}$ & $\mathrm{pg} / \mathrm{m}^{3}$ & 30 & 5.3 & 6.8 & 3.3 & 3.9 & 30 & 4.6 & 10.3 & 1.4 & 2.7 & 5.0 & 8.6 & 2.2 & 0.05 & 54.9 & 3.3 \\
\hline $\mathbf{V}$ & $\mathrm{ng} / \mathrm{m}^{3}$ & 30 & 2.4 & 1.6 & 2.0 & 2.0 & 30 & I.I & 0.52 & 0.95 & 0.97 & 1.8 & 1.4 & 1.4 & 0.47 & 6.3 & 1.3 \\
\hline Zn & $\mathrm{ng} / \mathrm{m}^{3}$ & 30 & 28.7 & 13.0 & 26.4 & 15.1 & 30 & 63.0 & 38.2 & 51.4 & 58.0 & 45.8 & 33.1 & 36.8 & 13.9 & 159 & 32.9 \\
\hline $\mathbf{N O}_{2} \dagger$ & $\mu \mathrm{g} / \mathrm{m}^{3}$ & 32 & 76.1 & 13.6 & 75.0 & 17.5 & 35 & 65.5 & 13.3 & 64.0 & 14.6 & 70.6 & 14.4 & 69.0 & 27.6 & 102 & 20.9 \\
\hline cot & $\mathrm{mg} / \mathrm{m}^{3}$ & 32 & 2.1 & 0.3 & 2.1 & 0.50 & 34 & 12.3 & 4.9 & 11.5 & 6.1 & 7.4 & 6.2 & 5.0 & 1.6 & 28.9 & 10.5 \\
\hline $\mathbf{O}_{3} \ddagger$ & $\mu g / \mathrm{m}^{3}$ & 32 & 70.9 & 12.5 & 69.8 & 16.9 & 34 & 16.0 & 8.1 & 14.3 & 10.0 & 42.6 & 29.5 & 30.8 & 6.6 & 95.3 & 58.7 \\
\hline $\mathrm{SO}_{2} \ddagger$ & $\mu \mathrm{g} / \mathrm{m}^{3}$ & 32 & 4.7 & 1.8 & 4.3 & 2.5 & 35 & 7.9 & 2.2 & 7.6 & 3.9 & 6.4 & 2.6 & 5.8 & 1.2 & 11.6 & 4.0 \\
\hline $\mathbf{T}$ & ${ }^{\circ} \mathrm{C}$ & 32 & 23.7 & 1.9 & 23.7 & 3.3 & 35 & 9.5 & 2.1 & 9.3 & 2.7 & 16.3 & 7.4 & 14.5 & 5.3 & 27.0 & 14.3 \\
\hline RelHum & $\%$ & 32 & 46.5 & 10.2 & 45.4 & 14.0 & 35 & 66.7 & 13.5 & 65.1 & 14.0 & 57.0 & 15.7 & 54.8 & 29.0 & 87.0 & 24.0 \\
\hline BarP & $\underset{\mathrm{Hg}}{\mathrm{mm}}$ & 32 & 762 & 2.6 & 762 & 3.4 & 35 & 762 & 7.3 & 762 & 12.1 & 762 & 5.5 & 762 & 748 & 773 & 6.6 \\
\hline $\begin{array}{l}\mathrm{PM}_{2.5} \\
\text { Indoor§ }\end{array}$ & $\mu \mathrm{g} / \mathrm{m}^{3}$ & 28 & 24.7 & 7.8 & 23.7 & 9.0 & 31 & 27.0 & 12.0 & 24.4 & 18.8 & 25.9 & 10.2 & 24.1 & 10.2 & 56.5 & 14.4 \\
\hline
\end{tabular}

*Averages of $24 \mathrm{~h}$ concentrations measured at 2 locations.

tAverages of $24 \mathrm{~h}$ concentrations recorded at 5 fixed sites.

$\ddagger$ Averages of $24 \mathrm{~h}$ concentrations recorded at 2 fixed sites.

$\S$ Averages of $24 \mathrm{~h}$ concentrations measured at 3 study participants' homes per season.

observations, in the exposure or outcome variables, were not replaced with estimates.

The relationships between respiratory function indices and concentrations of air pollutants were analyzed using generalized estimating equations (GEE) for panel data [34]. An autoregressive correlation matrix of lag 1 was assumed, in order to account for possible correlations between repeated measures on the same subject. The statistical package STATA [35] was used for the analyses (XTGEE; the option "force" was specified in order to allow for unequally spaced observations). All the linear models included the within-subject between-period effect, using the dichotomous season variable (spring and winter). For the COPD and IHD panels, terms for daily mean temperature $\left({ }^{\circ} \mathrm{C}\right)$, relative humidity $(\%)$ and day of the week (weekday/weekend) were included in the regression models. For the asthmatics panel, temperature and humidity terms were included in the regression models along with $\beta-2$ agonist use (yes/no), while the dummy variable weekday/weekend was not, because only 8 out of 108 spirometries were done on Saturday and none on Sunday. We considered the possibility of a non-linear effect of temperature by introducing a temperature-squared term in the regression models; however, since no evidence of model improvement was found in any of the panel-specific analyses, only a linear term was left. The daily variability of pulmonary function was examined with respect to the mean pollutant concentrations of the previous 24 hours and to the cumulative exposures over the previous 48 and 72 hours. Results from the analyses of lung function indices are reported as changes in percentage of predicted values per $10 \mu \mathrm{g} / \mathrm{m}^{3}$ increase in pollutant concentrations (except for CO where the unit increase is $1 \mathrm{mg} / \mathrm{m}^{3}$ ). In order to assess the relative effects of metals, we report changes in lung function per interquartile range of increasing concentrations.

\section{Results}

\section{Air pollutant concentrations}

The distribution of environmental variable levels (pollutants and weather conditions) during the study period is described in Table 2. Average daily concentrations of both $\mathrm{PM}_{10}$ and $\mathrm{PM}_{2.5}$ were higher and more variable from day to day in winter than in spring. The two PM fractions did not exceed $123 \mu \mathrm{g} / \mathrm{m}^{3}$ and $100 \mu \mathrm{g} / \mathrm{m}^{3}$, respectively. The 24 $\mathrm{h} \mathrm{NO}$ city means did not show statistically significant differences by season. The daily variability of $\mathrm{CO}$ concentrations, on the contrary, was sensibly higher during the winter than in spring survey. As expected, outdoor $\mathrm{O}_{3}$ levels were higher and more variable during the spring survey, but never exceeded $100 \mu \mathrm{g} / \mathrm{m}^{3}$. Average $24 \mathrm{~h}$ concentrations of $\mathrm{SO}_{2}$ were low and showed little variability both in spring and winter. We decided, therefore, $a$ pri- 
Table 3: Correlations among pollutants and weather variables

\begin{tabular}{|c|c|c|c|c|c|c|c|c|c|c|}
\hline & $\mathrm{PM}_{2.5}$ & $\mathrm{PM}_{10-25}$ & $\mathrm{PM}_{10}$ & $\mathrm{NO}_{2}$ & $\mathbf{O}_{3}$ & CO & $\mathrm{SO}_{2}$ & $\mathbf{T}$ & RelHum & BarP \\
\hline $\mathrm{PM}_{2.5}$ & 1 & & & & & & & & & \\
\hline $\mathrm{PM}_{10-25}$ & 0.34 & I & & & & & & & & \\
\hline $\mathrm{PM}_{10}$ & 0.93 & 0.61 & 1 & & & & & & & \\
\hline $\mathrm{NO}_{2}$ & 0.43 & 0.51 & 0.45 & 1 & & & & & & \\
\hline $\mathrm{O}_{3}$ & -0.51 & 0.31 & -0.36 & 0.17 & I & & & & & \\
\hline CO & 0.67 & -0.09 & 0.55 & 0.05 & -0.87 & 1 & & & & \\
\hline $\mathrm{SO}_{2}$ & 0.34 & -0.16 & 0.21 & 0.01 & -0.61 & 0.65 & I & & & \\
\hline $\mathbf{T}$ & -0.31 & 0.56 & -0.10 & 0.36 & 0.79 & -0.74 & -0.56 & 1 & & \\
\hline RelHum & 0.17 & -0.37 & 0.06 & -0.36 & -0.62 & 0.54 & 0.43 & -0.48 & I & \\
\hline BarP & 0.65 & 0.24 & 0.56 & 0.47 & -0.15 & 0.28 & 0.18 & -0.15 & -0.17 & I \\
\hline
\end{tabular}

ori not to consider $\mathrm{SO}_{2}$ further in the analyses. Similarly, we did not include mean daily values of barometric pressure (BarP) in the regression models, due to its negligible daily variability.
In terms of relative concentrations, six out of 8 metals examined were more represented in the fine than in the coarse fraction of outdoor PM; therefore only metal concentrations from the $\mathrm{PM}_{2.5}$ fraction are reported in Table 2. $\mathrm{Fe}, \mathrm{Zn}$ and $\mathrm{Pb}$ were present in sizeable concentrations

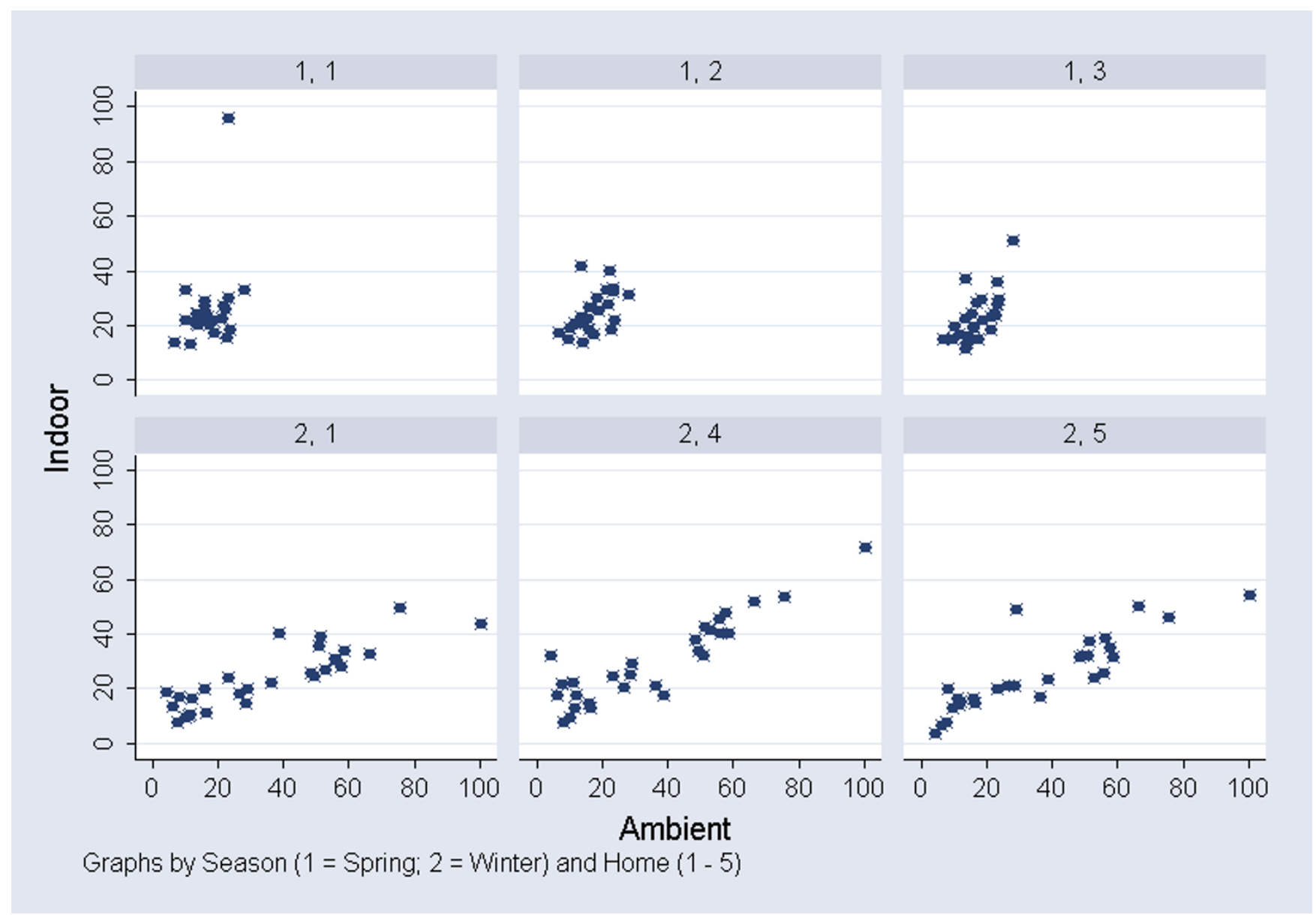

Figure I

Scatter plot of ambient* $\mathbf{P M}_{2.5}$ and indoor** concentrations $\left(\mu \mathrm{g} / \mathrm{m}^{3}\right)$, by seasont and home $¥ * A$ Averages of $\mathrm{PM}_{2.5} 24$ $\mathrm{h}$ concentrations $\left(\mu \mathrm{g} / \mathrm{m}^{3}\right)$ at two sites (Villa Ada and ISS). **PM $2.524 \mathrm{~h}$ indoor concentrations $\left(\mu \mathrm{g} / \mathrm{m}^{3}\right)$ in each home participating in the side validation study. ${ }^{\text {SSpring }}=\mathrm{I}$ and Winter $=2$. $\neq \mathrm{I}$ to 5 . 


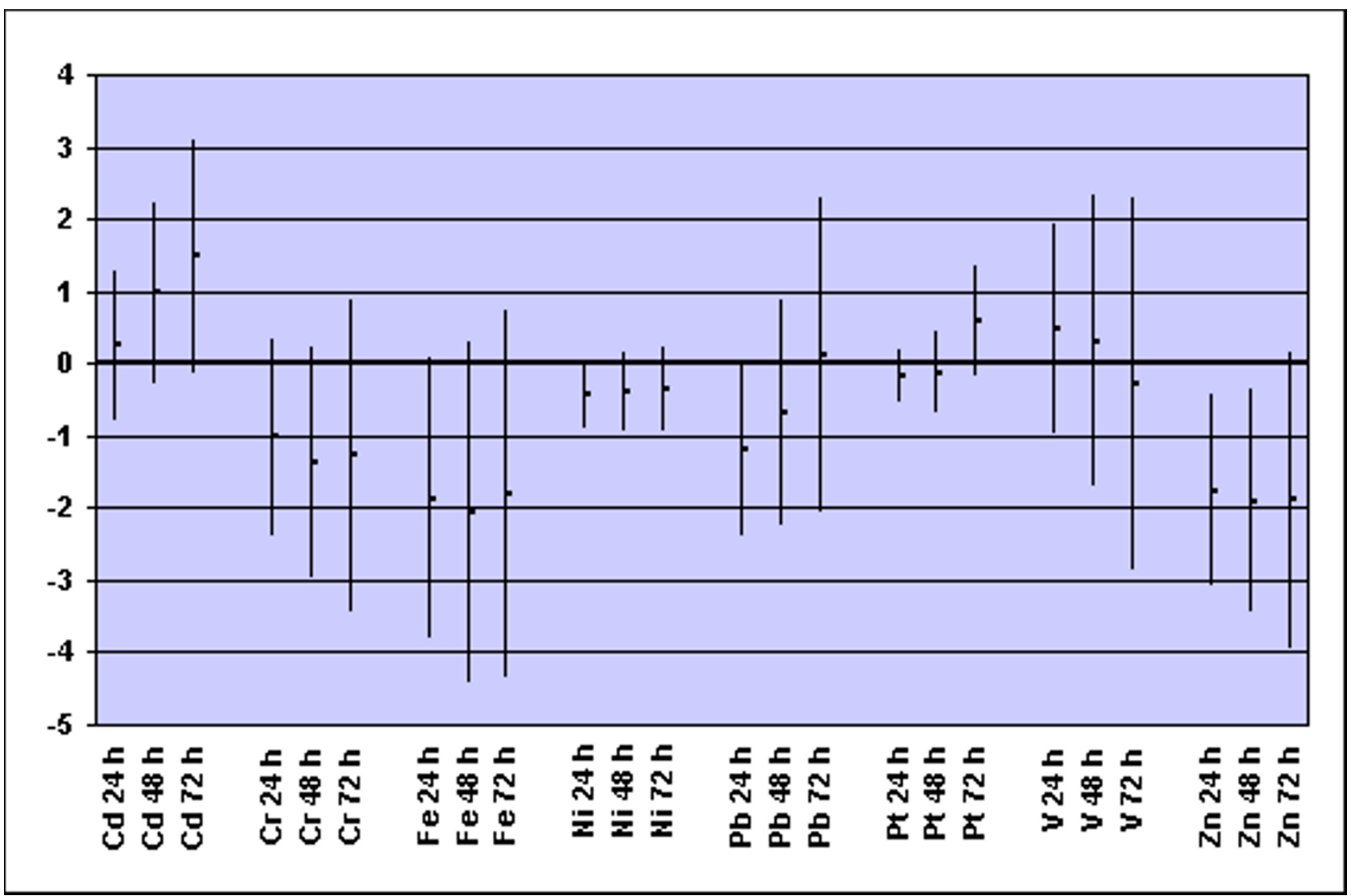

\section{Figure 2}

COPD panel: changes in FVC per interquartile increase of selected metals from $\mathbf{P M}_{2.5}$ samples during the previous 24, 48 or 72 hours* *Regression coefficients $\beta$ (dots) and 95\% confidence intervals (bars) from GEE models for panel data controlling for repeated individual observations, temperature, relative humidity, and day of the week, representing changes in FVC (\% of predicted) per interquartile range increase of metal concentration (see Table 2 for the IQR values).

in outdoor $\mathrm{PM}_{2.5}$ samples, whereas $\mathrm{Pt}, \mathrm{Cd}, \mathrm{V}, \mathrm{Cr}$ and $\mathrm{Ni}$ were only present in traces.

Correlations among ambient variables are reported in Table 3. Outdoor concentrations of fine $\left(\mathrm{PM}_{2.5}\right)$ and coarse $\left(\mathrm{PM}_{10-2.5}\right)$ particulate matter were weakly correlated. Daily mean levels of $\mathrm{PM}_{2.5}$ were directly correlated with barometric pressure, $\mathrm{CO}$ and $\mathrm{NO}_{2}$ concentrations, inversely correlated with $\mathrm{O}_{3}$ and temperature, and unrelated to relative humidity. Average daily concentrations of $\mathrm{PM}_{10-2.5}$ were positively correlated with $\mathrm{NO}_{2}$, temperature, and to a lesser extent with $\mathrm{O}_{3}$, inversely correlated with relative humidity, and not correlated with $\mathrm{CO} . \mathrm{NO}_{2}$ concentrations were neither correlated with $\mathrm{CO}$, nor with $\mathrm{O}_{3}$. Daily mean levels of $\mathrm{CO}$ and $\mathrm{O}_{3}$ showed a strong negative correlation.

Correlations between ambient concentrations of $\mathrm{PM}_{2.5}$ and each metal and between metals were also examined (data not shown). $\mathrm{PM}_{2.5}$ daily means were highly correlated with $\mathrm{Zn}, \mathrm{Cd}$ and $\mathrm{Pb}$ levels $(\rho=0.778,0.714$ and 0.694 respectively), moderately correlated with $\mathrm{Cr}, \mathrm{Pt}, \mathrm{Ni}$ and $\mathrm{Fe}(\rho=0.565,0.491,0.475$ and 0.463 respectively), and not correlated with vanadium concentrations $(\rho=$ 0.151 ). Fe concentrations were scarcely correlated with both $\mathrm{Zn}$ and $\mathrm{Pb}(\rho=0.318$ and 0.328$)$, and moderately correlated with Pt $(\rho=0.564)$. Pt was scarcely correlated with $\mathrm{Zn}$ and $\mathrm{Pb}(\rho=0.299$ and 0.421$)$. $\mathrm{Zn}$ and $\mathrm{Pb}$ concentrations were moderately correlated $(\rho=0.663)$.

Daily indoor concentrations of $\mathrm{PM}_{2.5}$ (averages of $24 \mathrm{~h}$ samples collected at the homes of three subjects per survey) were highly correlated with average ambient $\mathrm{PM}_{2.5}$ ( $\rho$ $=0.81, \mathrm{p}<0.01)$. A reverse $\mathrm{PM}_{2.5}$ indoor/outdoor ratio was evident in the two seasons. Concordance was higher during the winter survey $(\rho=0.91, p<0.01)$ than in spring $(\rho=0.59, p=0.01)$, apparently due to a greater daily variability of ambient $\mathrm{PM}_{2.5}$ concentrations in winter 


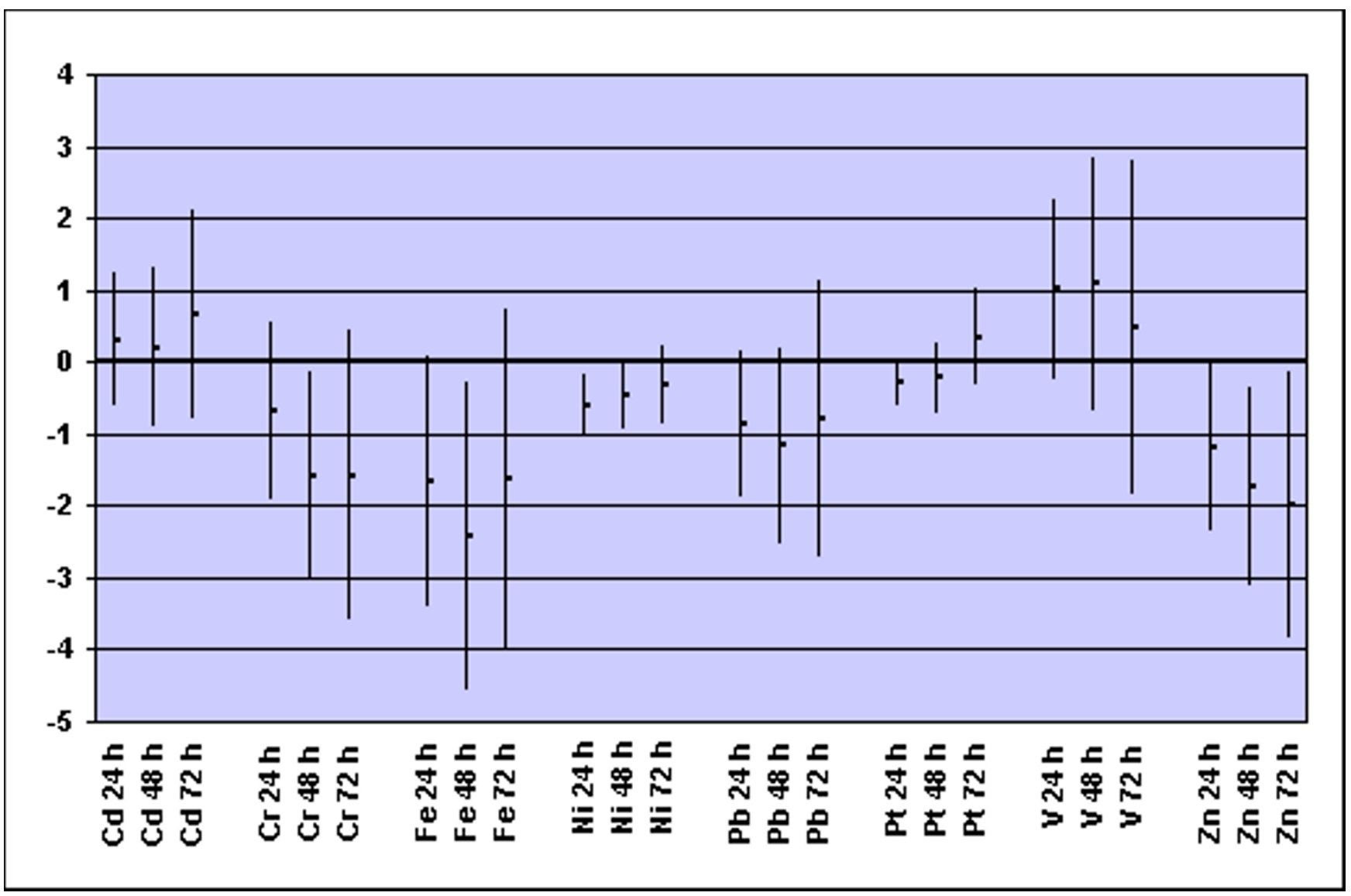

Figure 3

COPD panel: changes in FEV , per interquartile increase of selected metals from PM $_{2.5}$ samples during the previous 24, 48 or 72 hours* *Regression coefficients $\beta$ (dots) and $95 \%$ confidence intervals (bars) from GEE models for panel data controlling for repeated individual observations, temperature, relative humidity, and day of the week, representing changes in $\mathrm{FEV}_{\mathrm{I}}$ (\% of predicted) per interquartile range increase of metal concentration (see Table 2 for the IQR values).

than in spring, and not to home-specific characteristics (Figure 1).

\section{Lung function}

We observed a negative association between ambient $\mathrm{PM}_{2.5}$ and $\mathrm{PM}_{10}$ and respiratory function (FVC and $\mathrm{FEV}_{1}$ ) in the COPD panel (Table 4). The effect on FVC was evident both at a short lag $(24 \mathrm{~h})$ and in relation to cumulative exposures over the previous 24 and 48 hours. The effect on $\mathrm{FEV}_{1}$ appeared only when 72 hours of exposure were accumulated. A FEV 1 reduction was also seen with increasing $\mathrm{NO}_{2}$ concentrations during the previous 24 and 48 hours. In the asthmatic panel, we observed decreasing values of $\mathrm{FEV}_{1}$ related to cumulative exposure to $\mathrm{NO}_{2}$ concentrations during the preceding 24, 48, and 72 hours (Table 4). No association between respiratory function indices and average concentrations of any of the pollutants (neither at various lags, nor as cumulative exposure over 48 or $72 \mathrm{~h}$ ) was observed among IHD patients (Table 4 ).
In the COPD panel, $\mathrm{Zn}$ concentrations were associated with FVC and $\mathrm{FEV}_{1}$ decrements at single $24 \mathrm{~h}$ lag and at cumulative $48 \mathrm{~h}$ and $72 \mathrm{~h}$ lags (Figures 2 and 3 ). The associations were similar in size but less consistent for $\mathrm{Fe}$ and Ni. No statistically significant negative association between concentrations of metals and lung function indices was observed in the asthmatic and IHD panels (data not shown).

In the group of asthmatics, a total of 107 measurements of NO concentrations in exhaled breath were performed. Overall, there was no clear association of the various pollutants with this biological marker of inflammation.

\section{Discussion}

This study suggests an effect of fine particles on lung function of COPD patients. The metallic content of $\mathrm{PM}_{2.5}$ seems to be of importance, given the observed negative 
Table 4: Variations in respiratory function per unit increase of air pollutant concentrations in the three panels

\begin{tabular}{|c|c|c|c|c|c|c|c|c|c|c|c|c|c|c|c|c|c|c|c|c|}
\hline \multirow{2}{*}{$\begin{array}{l}\text { Pollutant } \\
\text { increase } \\
\text { Panel }\end{array}$} & \multirow[b]{2}{*}{ Outcome } & \multirow[b]{2}{*}{ Time } & \multicolumn{3}{|c|}{$\begin{array}{c}\mathbf{P M}_{2.5} \\
10 \mu \mathbf{g} / \mathbf{m}^{3}\end{array}$} & \multicolumn{3}{|c|}{$\begin{array}{l}\mathbf{P M}_{10-2.5} \\
10 \mu \mathbf{g} / \mathbf{m}^{3}\end{array}$} & \multicolumn{3}{|c|}{$\begin{array}{c}\mathbf{P M}_{10} \\
10 \mu \mathrm{g} / \mathrm{m}^{3}\end{array}$} & \multicolumn{3}{|c|}{$\begin{array}{c}\mathrm{NO}_{2} \\
10 \mu \mathrm{g} / \mathrm{m}^{3}\end{array}$} & \multicolumn{3}{|c|}{$\begin{array}{c}\mathrm{CO} \\
\mathrm{I} \mathrm{mg} / \mathrm{m}^{3}\end{array}$} & \multicolumn{3}{|c|}{$\begin{array}{c}O_{3} \\
10 \mu \mathrm{g} / \mathrm{m}^{3}\end{array}$} \\
\hline & & & $\beta *$ & SE $(\beta)$ & $\mathbf{p}$ & $\beta$ & SE $(\beta)$ & $\mathbf{p}$ & $\beta$ & SE $(\beta)$ & p & $\beta$ & SE $(\beta)$ & p & $\beta$ & SE $(\beta)$ & $\mathbf{p}$ & $\beta$ & SE $(\beta)$ & p \\
\hline \multirow[t]{6}{*}{ COPD } & & $24 \mathrm{n}$ & -0.80 & 0.36 & 0.027 & -1.32 & 1.06 & 0.210 & -0.66 & 0.30 & 0.027 & -0.72 & 0.49 & 0.139 & -0.14 & 0.15 & 0.353 & 0.01 & 0.57 & 0.983 \\
\hline & ) & $48 \mathrm{~h} \ddagger$ & -0.89 & 0.41 & 0.031 & -1.46 & 1.31 & 0.265 & -0.75 & 0.35 & 0.032 & -0.43 & 0.58 & 0.463 & -0.13 & 0.18 & 0.497 & 0.18 & 0.65 & 0.783 \\
\hline & & $72 \mathrm{~h} \S$ & -1.10 & 0.55 & 0.044 & -1.38 & 1.53 & 0.367 & -0.94 & 0.47 & 0.045 & -0.10 & 0.70 & 0.886 & 0.15 & 0.23 & 0.508 & -0.03 & 0.86 & 0.977 \\
\hline & & $24 \mathrm{~h}^{\dagger}$ & -0.47 & 0.33 & 0.149 & -0.59 & 0.95 & 0.532 & -0.37 & 0.27 & 0.167 & -1.16 & 0.41 & 0.005 & -0.05 & 0.13 & 0.725 & -0.20 & 0.50 & 0.687 \\
\hline & FEV $_{1}(\%)$ & $48 h \neq$ & -0.69 & 0.37 & 0.061 & -1.01 & 1.19 & 0.396 & -0.58 & 0.31 & 0.067 & -1.38 & 0.49 & 0.005 & -0.12 & 0.16 & 0.467 & 0.31 & 0.56 & 0.578 \\
\hline & & $72 \mathrm{~h} \S$ & -1.06 & 0.50 & 0.032 & -0.90 & 1.42 & 0.524 & -0.87 & 0.43 & 0.040 & -0.94 & 0.60 & 0.117 & -0.03 & 0.20 & 0.900 & 0.68 & 0.74 & 0.363 \\
\hline \multirow[t]{6}{*}{ Asthma } & & $24 \mathrm{~h}^{\dagger}$ & -0.14 & 0.29 & 0.617 & -0.17 & 0.75 & 0.822 & -0.12 & 0.24 & 0.621 & -0.53 & 0.31 & 0.081 & 0.02 & 0.12 & 0.842 & -0.33 & 0.41 & 0.416 \\
\hline & FVC (\%) & $48 \mathrm{~h} \neq$ & -0.07 & 0.33 & 0.825 & -0.36 & 0.91 & 0.695 & -0.09 & 0.29 & 0.750 & -0.59 & 0.32 & 0.065 & -0.001 & 0.13 & 0.995 & 0.02 & 0.42 & 0.957 \\
\hline & & $72 \mathrm{~h} \S$ & -0.06 & 0.39 & 0.886 & -0.24 & 1.07 & 0.824 & -0.08 & 0.36 & 0.836 & -0.54 & 0.37 & 0.149 & -0.06 & 0.16 & 0.700 & 0.14 & 0.50 & 0.782 \\
\hline & & $24 \mathrm{~h}^{\dagger}$ & -0.30 & 0.34 & 0.372 & -0.67 & 0.89 & 0.448 & -0.28 & 0.28 & 0.317 & -1.10 & 0.35 & 0.002 & -0.05 & 0.14 & 0.704 & -0.41 & .50 & 0.421 \\
\hline & FEV $_{\mid}(\%)$ & $48 \mathrm{~h} \ddagger$ & -0.36 & 0.39 & 0.347 & -1.19 & 1.07 & 0.265 & -0.40 & 0.34 & 0.239 & -1.28 & 0.37 & 0.001 & -0.16 & 0.15 & 0.292 & -0.01 & 0.51 & 0.983 \\
\hline & & $72 \mathrm{~h} \S$ & -0.40 & 0.46 & 0.384 & -0.51 & 1.26 & 0.689 & -0.40 & 0.43 & 0.351 & -1.17 & 0.44 & 0.007 & -0.28 & 0.18 & 0.126 & 0.46 & 0.60 & 0.449 \\
\hline \multirow[t]{6}{*}{ IHD } & & $24 \mathbf{h}^{\dagger}$ & 0.37 & 0.26 & 0.164 & 0.37 & 0.73 & 0.617 & 0.28 & 0.22 & 0.198 & 0.15 & 0.29 & 0.612 & 0.176 & 0.101 & 0.081 & 0.58 & 0.33 & 0.077 \\
\hline & FVC (\%) & $48 \mathrm{~h} \neq$ & 0.51 & 0.29 & 0.082 & -0.25 & 0.88 & 0.779 & 0.35 & 0.25 & 0.160 & -0.06 & 0.37 & 0.868 & 0.132 & 0.120 & 0.271 & 0.36 & 0.42 & 0.392 \\
\hline & & $72 \mathrm{~h} \S$ & 0.73 & 0.40 & 0.069 & 0.67 & 1.04 & 0.519 & 0.59 & 0.34 & 0.079 & 0.36 & 0.47 & 0.440 & 0.132 & 0.165 & 0.425 & 0.08 & 0.60 & 0.898 \\
\hline & & $24 \mathbf{h}^{\dagger}$ & 0.43 & 0.33 & 0.192 & 0.25 & 0.86 & 0.770 & 0.32 & 0.27 & 0.240 & -0.24 & 0.36 & 0.513 & 0.204 & 0.120 & 0.088 & 0.57 & 0.39 & 0.144 \\
\hline & FEv $1(\%)$ & $48 \mathrm{~h} \neq$ & 0.55 & 0.34 & 0.106 & -0.23 & 1.02 & 0.818 & 0.38 & 0.29 & 0.193 & 0.00 & 0.44 & 0.994 & 0.114 & 0.142 & 0.420 & 0.53 & 0.50 & 0.288 \\
\hline & & $72 h^{\S}$ & 0.66 & 0.47 & 0.157 & 0.18 & 1.19 & 0.877 & 0.49 & 0.39 & 0.214 & 0.21 & 0.56 & 0.710 & 0.159 & 0.194 & 0.412 & 0.65 & 0.70 & 0.354 \\
\hline
\end{tabular}

*Regression coefficient from GEE models for panel data controlling for repeated individual observations, temperature, relative humidity, and day of the week (COPD and IHD panels) or $\beta-2$ stimulant inhalation (asthma panel), representing the change in lung function index (\% of predicted) per unit increase of pollutant concentration. panels) or $\beta-2$ stimulant inhalation (asthma panel)
†Concentration during the previous 24 hours.

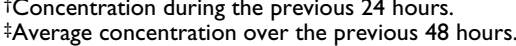

$\S$ Average concentration over the previous $72 \mathrm{~h}$.

effects of $\mathrm{Zn}, \mathrm{Fe}$ and Ni concentrations on lung function indices. $\mathrm{NO}_{2}$ also was associated with $\mathrm{FEV}_{1}$ decrements among COPD cases. On the other hand, no effects of $\mathrm{PM}_{2.5}$ were found among asthmatics, whose respiratory function seemed to be negatively influenced by ambient $\mathrm{NO}_{2}$ concentrations. No pollutant-related lung function changes were observed among IHD subjects, with no preexisting lung impairment.

We acknowledge several limitations of the study. Lack of personal exposure measurements is an important shortcoming. Lifestyles and housing conditions among our study subjects were not homogenous, and we cannot expect outdoor $\mathrm{PM}_{2.5}$ concentrations in our study to be a perfect indicator of personal exposure variability, as it was reported among elderly subjects residing in a retirement facility [36,37]. However, the good correlation we observed between day-to-day variations in average outdoor and indoor $\mathrm{PM}_{2.5}$ should mitigate the possibility that findings among COPD patients are entirely due to errors in estimating personal exposure variability. Moreover, despite the high number of repeated observations per subject, the reduced number of patients in each diagnostic category gives a low power to the study, thus we cannot exclude the possibility that small effects were not detected because of the reduced sample size. Last, the present study shares with other studies of air pollution related health effects the drawback of multiple statistical testing.
There are however strengths of the study that are worth underlining. They include: (i) supervised lung function tests; (ii) many repeated observations per patient, which allowed accounting for within-subject variability; (iii) a variety of measured urban pollutants, including fine particles, coarse particles and transition metals. Furthermore, in the present study no association between respiratory function indices and average ambient concentrations of any pollutants was observed among IHD cases, whereas effects of the fine fraction of ambient particulate on lung function among COPD subjects were detected, which had a strong a priori hypothesis. In the light of such results, it seem less likely that the associations observed among COPD and asthmatic patients are chance findings due to the great number of relationships examined.

After considering validity issues, it is worth noting the results of other published works. To our knowledge, only two studies have evaluated lung function by supervised spirometry in relation to daily variation in air pollution among adults with COPD. In the panel study of Pope and Kanner [25], based on 2 repeated observations of 251 smokers with mild to moderate COPD, a $10 \mu \mathrm{g} / \mathrm{m}^{3}$ increase in $\mathrm{PM}_{10}$ was associated with an average decrease in $\mathrm{FEV}_{1}$ equal to approximately $0.2 \%$. Brauer et al. [26], in their panel study of 16 COPD cases with moderate airway obstruction $\left(\mathrm{FEV}_{1}\right.$ at baseline $\left.\geq 0.75 \mathrm{l}\right)$ observed a non-significant $1.1 \%$ decrease of $\mathrm{FEV}_{1}$ for $10 \mu \mathrm{g} / \mathrm{m}^{3}$ increase in ambient $\mathrm{PM}_{2.5}$. In four other studies [19-22], possible pollution-related effects on pulmonary function in COPD 
cases were examined by unsupervised measurements of peak expiratory flow (PEF). To our knowledge, our study is the first that was able to document a specific role of fine particles on lung function of COPD patients.

PM-related exacerbation of chronic obstructive lung disease may be sustained by multiple direct and indirect mechanisms $[5,38,39]$. There is empirical evidence and experimental support for direct damages to the respiratory mucosa (increased permeability and reduced mucociliar activity), for oxidative damage, and for secondary toxic effects mediated by pro-inflammatory cytokines. Relative to healthy subjects, patients with moderate-to-severe airway obstruction receive an increased dose from ultra fine particle exposure [40]. Transition metals [7,8], as well as ultra fine particles [6], may induce oxidative stress and inflammatory response. We are not aware of previous panel studies of adult COPD cases examining pulmonary function changes in relation to the metallic content of airborne PM. The exploratory analyses presented in this paper suggest that metals from inhaled particulate have a biological effect on pulmonary function. The results on $\mathrm{Zn}$ and $\mathrm{Fe}$ are of specific interest. Both metals present in the fine fraction are likely to be traffic related as they originate from engine oils, brake, engine, exhaust systems and tire wear [41]. They have a high water solubility which has been directly related to oxidative damage [42].

Results from the asthmatic panel suggest a negative influence of $\mathrm{NO}_{2}$ on $\mathrm{FEV}_{1}$, but no effect of fine particles. Our finding that $\mathrm{NO}_{2}$ is related to lung function decrements both among COPD and asthma patients is of interest. It is difficult to believe that $\mathrm{NO}_{2}$ per se is responsible of the observed effects, given its low intrinsic toxicity. It has been suggested, however, that $\mathrm{NO}_{2}$ may be considered a very good marker of the combustion mixture from traffic sources, in particular of ultra fine particles [43].

No effect of $\mathrm{O}_{3}$ concentrations on the respiratory function of asthmatics was detected, even when the analysis was restricted to the spring survey. The latter finding could be explained by the relatively good clinical conditions of the asthmatics included in the study (all in the mild intermittent stage), the relatively low levels of $\mathrm{O}_{3}$ recorded during the study period, or simply lack of power. Although many panel studies of adult asthmatics have reported associations between asthma symptoms and both PM and $\mathrm{O}_{3}$ $[13,14]$, inconsistent results were observed with regard to lung function. Moseholm and coworkers [16] found that increased levels of $\mathrm{SO}_{2}$ and $\mathrm{NO}_{2}$ corresponded synergistically to decreased peak flow at levels above $40 \mu \mathrm{g} / \mathrm{m}^{3}$. In the asthmatic panel studied by Taggart et al. [24], changes in bronchial hyper-responsiveness were significantly correlated with $24 \mathrm{~h}$ mean concentrations of $\mathrm{SO}_{2}, \mathrm{NO}_{2}$ and black smoke, none of the criteria air pollutants seemed to affect $\mathrm{FEV}_{1}$, while previous-day $\mathrm{NO}_{2}$ levels were associated with FVC decrements. Ambient $\mathrm{PM}_{10}$ concentrations negatively affected PEF readings among the asthmatics followed by Peters et al. [17], with especially strong effects due to the number of ultra fine particles. Higgins et al. [19] observed PEF decrements associated with $\mathrm{SO}_{2}$ and $\mathrm{O}_{3}$ among the methacolin-reactors in their panel, but no independent effect of ambient $\mathrm{NO}_{2}$ levels. On the other hand, among the asthmatics followed by Hiltermann et al. [18], ambient concentrations of $\mathrm{O}_{3}, \mathrm{PM}_{10}$, black smoke and $\mathrm{NO}_{2}$ were found to be associated with increased symptom reports, but not with decreased PEF readings.

\section{Conclusion}

In conclusion our study, despite its limitations, suggests that the short-term negative impact of exposure to relatively low concentrations of air pollutants on lung function is limited to individuals with already impaired respiratory health. The fine fraction of ambient PM seems responsible for the observed effects among COPD cases, with zinc and iron having a potential role. These hints require confirmation from larger and more focused panel studies, using appropriate methods to overcome the problem of multiple comparisons [44].

\author{
Abbreviations \\ AAS = Atomic absorption spectrometry \\ BarP $=$ Barometric pressure \\ $\mathrm{BMI}=$ Body mass index [weight $(\mathrm{kg}) /$ height $\left.^{2}(\mathrm{~m})\right]$ \\ ${ }^{\circ} \mathrm{C}=$ Celsius degrees \\ $\mathrm{Cd}=$ Cadmium \\ $\mathrm{CO}=$ Carbon monoxide
}

$\mathrm{COHb}=$ Carboxyhemoglobin

COPD = Chronic obstructive pulmonary disease

$\mathrm{Cr}=$ Chrome

$\mathrm{Fe}=$ Iron

$\mathrm{FEV}_{1}=$ Forced expiratory volume in 1 second (\% of predicted)

FVC $=$ Forced vital capacity ( $\%$ of predicted)

GEE $=$ Generalized estimating equations

GMean $=$ Geometric mean 
$\mathrm{HbO}_{2}=$ Arterial blood oxygen saturation

IHD = Ischemic heart disease

$\mathrm{IQR}=$ Interquartile range

$\mathrm{IR}=$ Infrared

Mean $=$ Arithmetic mean

MEM = Micro Environmental Monitor

$\operatorname{Max}=$ Maximum

Min $=$ Minimum

$\mathrm{Mm} \mathrm{Hg}=$ Millimeters of mercury

$\mu \mathrm{g} / \mathrm{m}^{3}=$ Micrograms per cubic meterng $/ \mathrm{m}^{3}=$ Nanograms per cubic meter

$\mathrm{Ni}=$ Nickel

$\mathrm{NO}=$ Nitric oxide

$\mathrm{NO}_{2}=$ Nitrogen dioxide

$\mathrm{O}_{3}=$ Ozone

Obs $=$ Number of observations

PEF $=$ Peak expiratory flow

$\mathrm{Pb}=$ Lead

$\mathrm{PM}=$ Particulate matter

$\mathrm{PM}_{10}=$ Particulate matter with aerodynamic diameter less than $10 \mu \mathrm{m}$

$\mathrm{PM}_{10-2.5}=$ Particulate matter with aerodynamic diameter between 10 and $2.5 \mu \mathrm{m}$

$\mathrm{PM}_{2.5}=$ Particulate matter with aerodynamic diameter less than $2.5 \mu \mathrm{m}$

$\mathrm{Pt}=$ Platinum

PTFE $=$ Polytetrafluoroethylene

RelHum = Relative humidity

$\mathrm{SD}=$ Standard deviation

$\mathrm{SO}_{2}=$ Sulphur dioxide

\author{
$\mathrm{SpO}_{2}=$ Partial oxygen pressure \\ $\mathrm{T}=$ Temperature \\ UCSC = Catholic University Hospital \\ $\mathrm{UV}=$ Ultraviolet \\ $\mathrm{V}=$ Vanadium \\ $\mathrm{Zn}=$ Zinc
}

\section{Competing interests}

The author(s) declare that they have no competing interests.

\section{Authors' contributions}

SL conceived the study, participated in its design and in data analysis, coordinated its realization, made substantial contribution to the interpretation of results, and drafted the manuscript. FF conceived the study, participated in its design, made substantial contribution to the interpretation of results and participated in drafting the manuscript. RP participated in the design of the study, selected the study subjects and coordinated the clinical monitoring. II participated in data acquisition and data management, and carried out the statistical analysis. PM participated in the design and in the coordination of the data collection. VF participated in the data management and statistical analysis. AM and GZ coordinated the monitoring of atmospheric pollutants and the analysis of environmental samples. BDO participated in design of the study and made substantial contribution in the interpretation of results.

\section{Acknowledgements}

The authors are grateful to Giorgio Cattani and Giordano Stacchini for the collection of PM samples, and to Drs Raffaele Antonelli Incalzi, Salvatore Basso, Raffaella Tiziana Benedetto, Anna Maria Della Corte, Leonello Fuso, Carmela Maiolo, Sandra Sammarro, Maria Serra, Salvatore Spadaro,

Lorenzo Maria Tramaglino for the spirometries. A special thank goes to the two referees, Dr. Amanda Wheeler and Dr. Lewis Pepper, whose thoughtful suggestions helped us to greatly improve the presentation of results. The study has been funded by the Italian Ministry for the Environment (PR22-IS, 1998-2002).

\section{References}

I. Brunekreef B, Holgate ST: Air pollution and health. Lancet 360: I233-1242. 2002 Oct 19

2. Committee on Research Priorities for Airborne Particulate Matter, National Research Council. In Research priorities for airborne particulate matter: I. Immediate priorities and a long-range research portfolio Washington, DC (USA): National Academy Press; 1998.

3. Utell MJ, Frampton MW: Who is susceptible to particulate matter and why? Inhal Toxicol 2000, I 2(Suppl I):37-40.

4. Forastiere F, D'lppoliti D, Pistelli R: Airborne particles are associated with increased mortality and hospital admissions for hearth and lung diseases. Eur Respir Mon 2002, 20:I-I5. 
5. MacNee W, Donaldson K: Mechanism of lung injury caused by PM $_{10}$ and ultrafine particles with special reference to COPD. Eur Respir J 2003, 21 (Suppl 40):47s-5 Is.

6. Kelly F): Oxidative stress: its role in air pollution and adverse health effects. Occup Environ Med 2003, 60:612-616.

7. Risom L, Moller P, Loft S: Oxidative stress-induced DNA damage by particulate air pollution. Mutat Res 2005, 592: I 19-137.

8. Roberts ES, Richards JH, Jaskot R, Dreher KL: Oxidative stress mediates air pollution particle-induced acute lung injury and molecular pathology. Inhal Toxicol 2003, I5:1327-1346.

9. Holgate ST, Sandstrom T, Frew AJ, Stenfors N, Nordenhall C, Salvi S, Blomberg A, Helleday R, Soderberg M: Health effects of acute exposure to air pollution. Part I: Healthy and asthmatic subjects exposed to diesel exhaust. Res Rep Health Eff Inst 2003, II 2: I-30. discussion 5|-67.

10. Lay JC, Bennett WD, Ghio AJ, Bromberg PA, Costa DL, Kim CS, Koren HS, Devlin RB: Cellular and biochemical response of the human lung after intrapulmonary instillation of ferric oxide particles. Am J Resp Cell Mol Biol 1999, 20:63I-642.

II. Zhou Y-M, Zhong C-Y, Kennedy IM, Pinkerton KE: Pulmonary responses of acute exposure to ultrafine iron particles in healthy adult rats. Environ Toxicol 2002, 18:227-235

12. Sunyer ]: Urban air pollution and chronic obstructive pulmonary disease. Eur Respir J 200I, 17:1024-1033.

13. Desqueyroux H, Momas I: Pollution atmosphérique et santé: une synthèse des études longitudinales de panel publiées de 1987 à 1998. Rev Epidemiol Sante Publique 1999, 47:361-375.

14. Desqueyroux H, Momas I: Impact à court terme de la pollution atmosphérique urbaine sur l'insufficence respiratoire par bronchopneumopathie chronique obstructive (BARPCO). Synthèse des études publiées de 1962 à Janvier 2000. Rev Epidemiol Sante Publique 200I, 49:6I-76.

15. Lebowitz MD, Collins L, Holberg CJ: Time series analyses of respiratory responses to indoor and outdoor environmental phenomena. Environ Res 1987, 43:332-341.

16. Moseholm L, Taudorf E, Frøsig A: Pulmonary function changes in asthmatics associated with low-levels $\mathrm{SO}_{2}$ and $\mathrm{NO}_{2}$ air pollution, weather, and medicine intake. Allergy 1993, 48:334-344.

17. Peters A, Wichmann HE, Tuch T, Heinrich J, Heyder J: Respiratory effects are associated with the number of ultrafine particles. Am J Respir Crit Care Med 1997, I 55: 1376-1383.

18. Hiltermann TJ, Stolk J, van der Zee SC, Brunekreef B, de Bruijne CR, Fischer PH, Ameling CB, Sterk PJ, Hiemstra PS, van Bree L: Asthma severity and susceptibility to air pollution. Eur Respir 1998 II:686-693.

19. Higgins BG, Francis HC, Yates CJ, Warburton CJ, Fletcher AM, Reid JA, Pickering CA, Woodcock AA: Effects of air pollution on symptoms and peak expiratory flow measurements in subjects with obstructive airways disease. Thorax 1995, 50:149-155.

20. Harre ES, Price PD, Ayrey RB, Toop LJ, Martin IR, Town GI: Respiratory effects of air pollution in chronic obstructive pulmonary disease: a three month prospective study. Thorax 1997, 52:1040-1044.

21. Linn WS, Gong HJr, Clark KW, Anderson KR: Day-to-day particulate exposures and health changes in Los Angeles area residents with severe lung disease. J Air Waste Manag Assoc 1999, 49:108-115.

22. van der Zee SC, Hoek G, Boezen MH, Schouten JP, van Wijnen JH, Brunekreef $B$ : Acute effects of air pollution on respiratory health of 50-70 yr old adults. Eur Respir / 2000, I5:700-709.

23. Shamoo DA, Linn WS, Peng RC, Solomon JC, Webb TL, Hackney JD, Gong $\mathrm{H}$ Jr: Time-activity patterns and diurnal variation of respiratory status in a panel of asthmatics: implication for short-term air pollution effects. J Expo Anal Environ Epidemiol 1994, 4: 133-148

24. Taggart SC, Custovic A, Francis HC, Faragher EB, Yates C], Higgins $B G$, Woodcock A: Asthmatic bronchial hyperresponsiveness varies with ambient levels of summertime air pollution. Eur Respir J 1996, 9: I |46-I I54.

25. Pope CA 3rd, Kanner RE: Acute effects of $\mathbf{P M}_{10}$ pollution on pulmonary function of smokers with mild to moderate chronic obstructive pulmonary disease. Am Rev Respir Dis 1993 , 1 47:1333-1340.

26. Brauer M, Ebelt ST, Fisher TV, Brumm J, Petkau AJ, Vedal S: Exposure of chronic obstructive pulmonary disease patients to particles: respiratory and cardiovascular health effects. Expo Anal Environ Epidemiol 200I, II :490-500.

27. National Heart, Lung, and Blood Institute (NIHLBI). In Guidelines for the diagnosis and management of asthma Bethesda, MD (USA): National Institute of Health (NIH), NIH Publication No 97-405I; 1997.

28. American Thoracic Society: Standardization of Spirometry, 1994 Update. Am J Respir Crit Care Med 1995, 152: I I07-II 36

29. Quanjer PH, Tammeling G], Cotes JE, Pedersen OF, Peslin R, Yernault $J C$ : Lung volumes and forced ventilatory flows. Report Working Party Standardization of Lung Function Tests, European Community for Steel and Coal. Official Statement of the European Respiratory Society. Eur Respir J Suppl 1993, 16:5-40.

30. Bernareggi $M$, Cremona : Measurements of exhaled nitric oxide in humans and animals. Pulm Pharmacol Ther 1999, 12:331-352.

31. US EPA: Air quality criteria for particulate matter 1996 [http:// cfpub.epa.gov/ncea/cfm/recordisplay.cfm]. US Environmental Protection Agency, Report n. EPA/600/P-95/00IaF

32. Cattani G, Stacchini G, D'Innocenzio F, Marconi A, Ziemacki G: Confronto tra campionatori per il prelievo della frazione di polveri aerodisperse $\mathbf{P M}_{10}$. In Proceedings of the II European Congress of Industrial Hygiene Edited by: Soleo L, Apostoli P, Cavallo D, Cottica D, Nano G, Ambrosi L. Pavia : Fondazione Maugeri; 4II-4I4 [Symposia - I Congressi della Fondazione Maugeri, vol 2.]; 2000. 30 June - 3 July 1999 Bari

33. European Standard I234I. In Air quality - Determination of the PMIO fraction of suspended particulate matter - Reference method and field test procedure to demonstrate reference equivalence of measurement methods Brussels: CEN; 1998.

34. Diggle PJ, Heagerty P, Liang K-Y, Zeger SL: Analysis of longitudinal data second edition. New York (USA): Oxford University Press, Oxford Statistical Science Series 25; 2002.

35. StataCorp: Stata Statistical Software Release 8.0 College Station, TX (USA): Stata Corporation; 2003.

36. Williams R, Suggs J, Zweidinger R, Evans G, Creason J, Kwok R, Rodes $C$, Lawless P, Sheldon L: The 1998 Baltimore particulate matter epidemiology-exposure study: Part I: Comparison of ambient, residential outdoor, indoor and apartment particulate matter monitoring. I Expo Anal Environ Epidemiol 2000, 10:518-532.

37. Williams R, Suggs J, Creason J, Rodes C, Lawless P, Kwok R, Zweidinger R, Sheldon L: The 1998 Baltimore particulate matter epidemiology-exposure study: Part 2. Personal exposure assessment associated with an elderly study population. J Expo Anal Environ Epidemiol 2000, 10:533-543.

38. White AJ, Gompertz S, Stockley RA: The aetiology of exacerbations of chronic obstructive pulmonary disease. Thorax 2003 , 58:73-80.

39. Tao F, Gonzales-Flecha B, Kobzik L: Reactive oxygen species in pulmonary inflammation by ambient particulate. Free Radic Biol Med 2003, 35:327-340.

40. Brown JS, Zeman KL, Bennett WD: Ultrafine particle deposition and clearance in the healthy and obstructed lung. Am J Respir Crit Care Med 2002, 166:1240-1247.

4I. Morawska L, Zhang J: Combustion sources of particles: I. Relevance of sources signatures. Chemosphere 2002, 49: 1045-1058.

42. Moreno T, Merolla L, Gibbons W, Greenwell L, Jones T, Richards R: Variations in the source, metal content and bioreactivity of technogenic aerosols: a case study from Port Talbot, Wales, UK. Sci Total Environ 2004, 333:59-73

43. Seaton A, Dennekamp M: Hypothesis: ill health associated with low concentrations of nitrogen dioxide - an effect of ultrafine particles? Thorax 2003, 58:1012-1015.

44. Bender R, Lange S: Adjusting for multiple testing - when and how? J Clin Epidemiol 200I, 54:343-349. 